\title{
Predicting Phosphorus Sorption onto Steel Slag Using a Flow-through Approach with Application to a Pilot Scale System
}

\author{
Chad J. Penn, Joshua M. McGrath \\ Oklahoma State University, Oklahoma, USA \\ E-mail: chad.penn@okstate.edu; mcgrathj@umd.edu \\ Received February 11, 2011; revised March 11, 2011; accepted March 31, 2011
}

\begin{abstract}
Reducing phosphorus (P) loads from soils to surface waters is necessary for solving the problem of eutrophication. Many industrial by-products have been shown to sorb appreciable amounts of dissolved $\mathrm{P}$ from solution and it has been proposed to use P sorption materials (PSMs) such as steel slag in landscape scale "filters" for trapping dissolved P in runoff. The objective of this study was to model the effect of retention time (RT) and P concentration on P sorption by steel slag and a surface modified slag in a flowthrough system. Sorption of P onto steel slag and rejuvenated-modified steel slag was measured using a traditional batch isotherm and a flow-through setting at several RTs and P concentrations. Flow-through data were used to produce a model that estimated P sorption based on RT and P concentration. The model was tested on a pilot-scale pond filter consisting of the same slag materials. For both the materials, flow-through tests indicated an increase in RT increased P removal efficiency but decreased the total amount of P removed at saturation. The Langmuir model developed from batch isotherms overestimated and underestimated $\mathrm{P}$ sorption in normal and rejuvenated slag respectively, relative to flow-through. Normal and rejuvenated slag removed 38 and $36 \%$ of $\mathrm{P}$ in the pilot-scale pond filter after 2 weeks of pumping. The Langmuir equation poorly predicted $\mathrm{P}$ sorption in the pond filter while the flow-through model produced reasonable estimates. Results suggest that flow-through methodology is necessary for estimating $\mathrm{P}$ sorption in the context of landscape P filters.
\end{abstract}

Keywords: Phosphorus, By-Products, Phosphorus Removal Structure

\section{Introduction}

Input of phosphorus $(\mathrm{P})$ to surface waters can contribute to eutrophication of receiving water bodies. Potential sources of $\mathrm{P}$ to surface waters include waste-water treatment plants, horticultural operations, and runoff from agricultural and urban/suburban land (including golf courses). In regard to runoff, dissolved $\mathrm{P}$ is the most difficult form to control since particulate losses are typically controlled by maintaining sufficient soil cover and reducing erosion [1]. Dissolved P loads in runoff are greatest from soils that are high in soil test $\mathrm{P}$ and soils with recent surface applications (not incorporated) of $\mathrm{P}$ [2-3].

Previous research has shown that application of $\mathrm{P}$ sorbing materials (PSMs) directly to high $\mathrm{P}$ soils or to animal manures prior to land application can reduce losses of dissolved in runoff during rainfall events [4-5].
However, such reductions in $\mathrm{P}$ runoff concentrations may be temporary since $\mathrm{P}$ is not truly removed from the system [6-7]. As an alternative, it has been suggested that PSMs could be used in a "P removal structure" or a constructed, isolated structure for treating $P$ rich runoff prior to reaching surface bodies of water [8]. Penn et al. [7] constructed a P removal structure in a surface water drainage ditch located on the Eastern Shore of Maryland, U.S. This structure contained an iron rich byproduct that possessed a high $\mathrm{P}$ sorption capacity. In a single rainfall event that lasted nearly $18 \mathrm{~h}$, the structure removed $99 \%$ of the dissolved $\mathrm{P}$ that entered it. One disadvantage of this material was that it had low hydraulic conductivity; therefore the amount of water that could be treated was limited.

A by-product from the steel industry that has potential for use in P removal structures is steel slag. 
Several studies have evaluated this $\mathrm{Ca}$ and $\mathrm{Fe}$ rich waste in regards to treating wastewater streams [9-10]. In addition, McDowell et al. [11] found that a mixture of "basic" and "melter" slag backfilled around subsurface drainage pipes overlaid by $\mathrm{P}$ rich topsoils was able to significantly reduce dissolved $\mathrm{P}$ concentrations in drainage waters. In another study, Shilton et al. [9] utilized a melter slag as a filter material at a wastewater treatment plant for 11 years and found that $77 \%$ of total $\mathrm{P}$ was removed during the first $5 \mathrm{yrs}$ of operation.

Based on the success of these field scale experiments, it is likely that steel slag would also serve well in removing $\mathrm{P}$ from passing runoff water in a $\mathrm{P}$ removal structure. However, the P sorption potential of steel slag will likely depend on the incoming P concentration and the contact or retention time (RT) of the solution with slag. In order to estimate the effectiveness and longevity of steel slag in P removal structures, it is necessary to examine the impact of solution $\mathrm{P}$ concentration and RT on P sorption. Many studies on P sorption onto slag have utilized a batch isotherm experiment $[10,12]$ which may not suitable in the context of $\mathrm{P}$ removal structures. Instead, a flow through column or cell may be necessary. In regard to the latter, most flow-through studies on slag have been conducted at high retention times $(>1 \mathrm{~h})$ and $P$ concentrations [13-15] that are more suited to wetland treatment systems and wastewater treatment as opposed to $\mathrm{P}$ removal structures for treating runoff.

In addition, any potential to increase the useful lifetime in which slag is able to remove $\mathrm{P}$ from runoff would likely increase the acceptance of such a practice. Drizo et al. [16] found that by initiating a rest period during $P$ additions to electric arc furnace (EAF) steel slag columns increased the total $\mathrm{P}$ sorption capacity of the material. However, chemical treatments to spent slag may also be effective at rejuvenating the $\mathrm{P}$ sorption material in situ.

The objective of this study was to model the effect of RT and $\mathrm{P}$ concentration on $\mathrm{P}$ sorption by slag and a surface modified slag in a flow through setting. Achievement of this objective will provide us with the information necessary for designing a future runoff $\mathrm{P}$ removal structure consisting of the same material.

\section{Materials and Methods}

\subsection{General Characterization of Sorption Materials}

Electric arc furnace (EAF) slag was collected from a steel mill (Tube City IMS) located in Ft. Smith, AR (U.S.). In order to increase the hydraulic conductivity, the material was sieved to achieve particle size 6.35 to 11 $\mathrm{mm}$. Previous work indicated that non-sieved EAF slag clogged after only $4 \mathrm{~d}$ in the pilot scale pond structure. Bulk density of the sieved slag used in all experiments was $1.8 \mathrm{~g} \cdot \mathrm{cm}^{-3}$. A surface modified slag product (i.e. rejuvenated slag) was produced and tested after "spent" $P$ saturated slag was treated with aluminum sulfate in an attempt to rejuvenate the slag. Details on the treatment process for production of the rejuvinated slag is described in detail below under "Large scale pond flowthrough experiment".

All analyses were conducted in triplicate. Material $\mathrm{pH}$ was measured with a $\mathrm{pH}$ meter using a solid:DI water ratio of 1:5. Alkalinity was determined by automatic titration (TitriLab 865; Radiometer Analytical, Villeurbanne Cedex, France) to $\mathrm{pH} 4.5$ on $2 \mathrm{~g}$ material suspended in 20 $\mathrm{mL}$ of DI water. Materials were ground prior to analysis of total elements by EPA 3051 digestion method [17]. Digestion solutions were analyzed for $\mathrm{Ca}, \mathrm{Mg}, \mathrm{S}, \mathrm{Fe}$, and $\mathrm{Al}$ by inductively coupled plasma atomic emission spectroscopy (ICP-AES). Samples were also extracted with DI water at a 1:10 solid:solution ratio for $1 \mathrm{~h}$ followed by filtration with a $0.45 \mu \mathrm{m}$ filter and analysis for $\mathrm{Ca}, \mathrm{Mg}, \mathrm{S}, \mathrm{Fe}$, and $\mathrm{Al}$ by ICP-AES. Each material was also analyzed for crystalline minerals by X-ray diffraction (XRD) on a Philips (now PANayltical; Almelo, Netherlands) powder x-ray diffractometer. Hydraulic conductivity was measured by the falling head method [18].

\subsection{Batch Experiment}

A standard batch isotherm was conducted on both slag materials using $2 \mathrm{~g}$ of sample and $16 \mathrm{~h}$ equilibration (shaking) in $30 \mathrm{~mL}$ solutions of $0,1,10,25,50$, and $100 \mathrm{mg} \cdot \mathrm{P} \cdot \mathrm{L}^{-1}$. P solutions were made using $\mathrm{KH}_{2} \mathrm{PO}_{4}$ and the matrix solution consisted of 5.6, 132, 110, 10, and $17 \mathrm{mg} \cdot \mathrm{L}^{-1}$ of $\mathrm{Mg}, \mathrm{Ca}, \mathrm{S}, \mathrm{Na}$, and $\mathrm{K}$, respectively adjusted to a $\mathrm{pH}$ of 7 . Reagent grade magnesium sulfate, calcium sulfate, sodium chloride, and potassium chloride were used to make the matrix. This matrix was chosen as it was found to be representative of agricultural runoff measured in a previous study [7]. After equilibration, solutions were centrifuged for 15 minutes and filtered through a $0.45 \mu \mathrm{m}$ filter prior to $\mathrm{P}$ analysis by the Murphy-Riley molybdate blue method [19]. P sorption was quantified by the difference between $P$ concentrations added and the final equilibrated concentrations. These values were applied to a nonlinear Langmuir using the following equation:

$$
S=\frac{S_{\max } K C}{1+K C}
$$

where $\mathrm{S}$ is the sorbed $\mathrm{P}$ concentration $\left(\mathrm{mg} \cdot \mathrm{kg}^{-1}\right), \mathrm{S}_{\max }$ is the maximum sorption capacity of the soil $\left(\mathrm{mg} \cdot \mathrm{kg}^{-1}\right)$, 


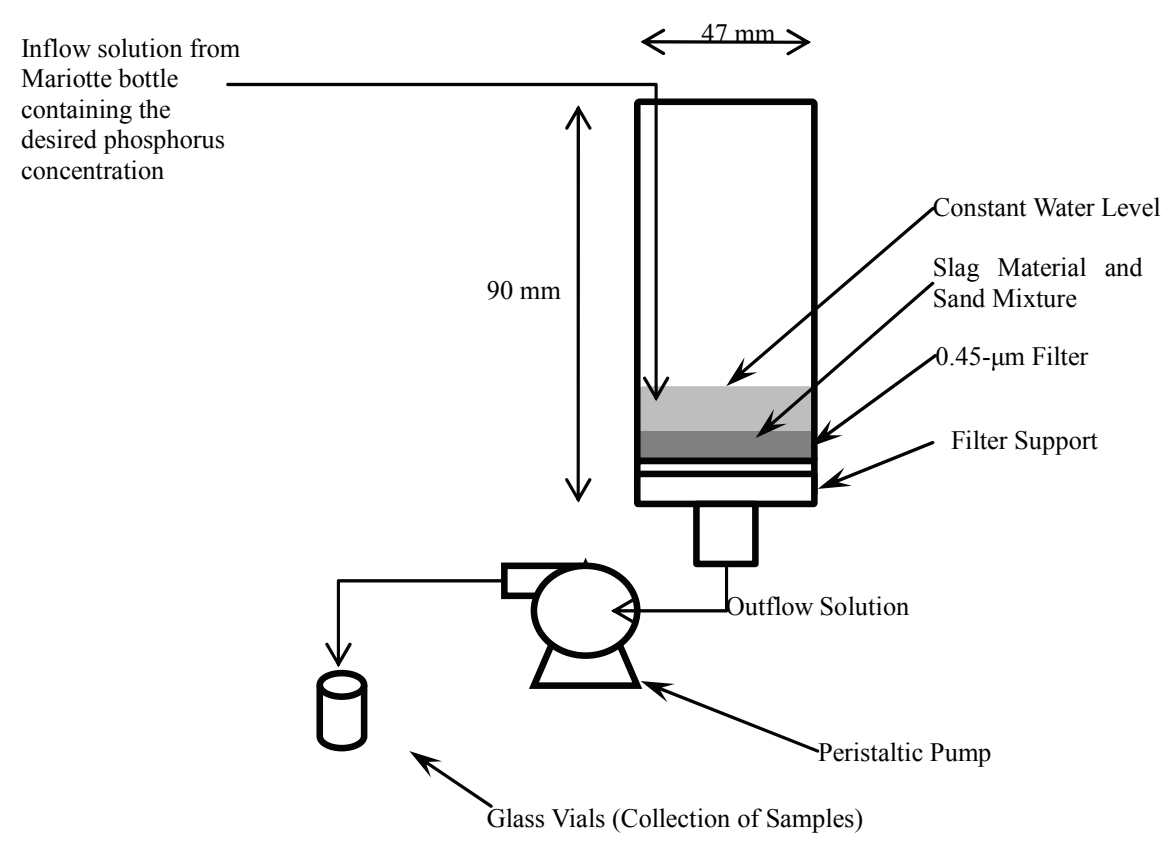

Figure 1. Diagram of the flow-through cells used to evaluate the effect of retention time and phosphorus concentration on $P$ sorption by slag and rejuvenated slag.

$\mathrm{K}$ is the Langmuir binding strength coefficient $\left(\mathrm{L} \cdot \mathrm{mg}^{-1}\right)$, and $\mathrm{C}$ is the equilibrium concentration $\left(\mathrm{mg} \cdot \mathrm{L}^{-1}\right)$. The best fit model parameters for the non-linear equation were obtained by finding the combinations of parameters that provided the best fit to the observed data. Specifically, this was done by using an Excel (Microsoft, 2003) spreadsheet as prepared and described by Bolster and Hornberger [20]. This program was designed to provide $\mathrm{K}$ and $\mathrm{S}_{\max }$ values, in addition to the "goodness-of-fit" indicator, model efficiency (E). An $\mathrm{E}$ value of 1 indicates a perfect fit of the data and $\mathrm{E}<0$ indicates that taking the average of all measured values would give a better prediction than the model [20].

\subsection{Laboratory Flow-Through Experiments}

To test the effect of retention time (RT) and $\mathrm{P}$ concentration on $\mathrm{P}$ sorption in a flow-through setting, flow-through cells were constructed as described in Desutter et al. [21]. Two g of slag was mixed with acid washed, lab-grade sand (pure Si sand, 14808-60-7; Acros organics, Morris Plains, New Jersey) in order to achieve a total pore volume of $3.2 \mathrm{~cm}^{3}$ (5 g of sand; $40 \%$ porosity) and then was placed in a flow-through cell. A $0.45 \mu \mathrm{m}$ filter was placed under materials and the bottom of the cell was connected to a single channel peristaltic pump (VWR variable rate "low flow" and "ultra low flow", 61161-354 and 54856-070) using plastic tubing. The desired RT $(\mathrm{RT}[\mathrm{min}]=$ pore volume $[\mathrm{mL}] /$ flow rate $\left[\mathrm{mL} \cdot \mathrm{min}^{-1}\right]$ ) was achieved by varying the pump flow rate which pulled solution through the cell (Figure 1). Flow rates required to achieve the desired RTs of $0.5,3,6$ and 8 min were $6.4,1.1,0.53$, and $0.40 \mathrm{~mL} \cdot \mathrm{min}^{-1}$, respectively. Essentially, the RT is the amount of time required for the solution to pass through the cell. A constant head Mariotte bottle apparatus was used to maintain a constant volume of $\mathrm{P}$ solution on the materials. Materials were subjected to flow for $5 \mathrm{~h}$ in which the "outflow" from the cells was sampled at $0,15,30,60$, $90,120,150,180,210,240,270$, and $300 \mathrm{~min}$. Solutions were analyzed for P by the Murphy-Riley molybdate blue method and $\mathrm{pH}$ (meter). Discrete P sorption onto materials was calculated at each sampling time as a percentage decrease in outflow relative to inflow P concentration (i.e. source bottle).

Five different $\mathrm{P}$ concentrations were tested; $0.5,1,5$, 10 , and $15 \mathrm{mg} \cdot \mathrm{L}^{-1}$. These $\mathrm{P}$ concentrations represent results from typical runoff studies conducted on recently surface applied manure and chemical fertilizer $\mathrm{P}$ sources and high $\mathrm{P}$ soils $[2,22]$. The matrix of each $\mathrm{P}$ solution was the same as that used in the batch isotherm experiment previously described. Four different RTs were tested at each P concentration: 0.5, 3, 6, and $8 \mathrm{~min}$. These RTs represent a reasonable amount of time for runoff water to pass through a $\mathrm{P}$ removal structure; while an excessive RT may be effective at P sorption, it will reduce the total amount of runoff that can be treated under high flow conditions [8]. All flow-through RT * $\mathrm{P}$ concentration combinations were duplicated for each material (normal and rejuvenated slag) resulting in a total of 80 experimental units. 

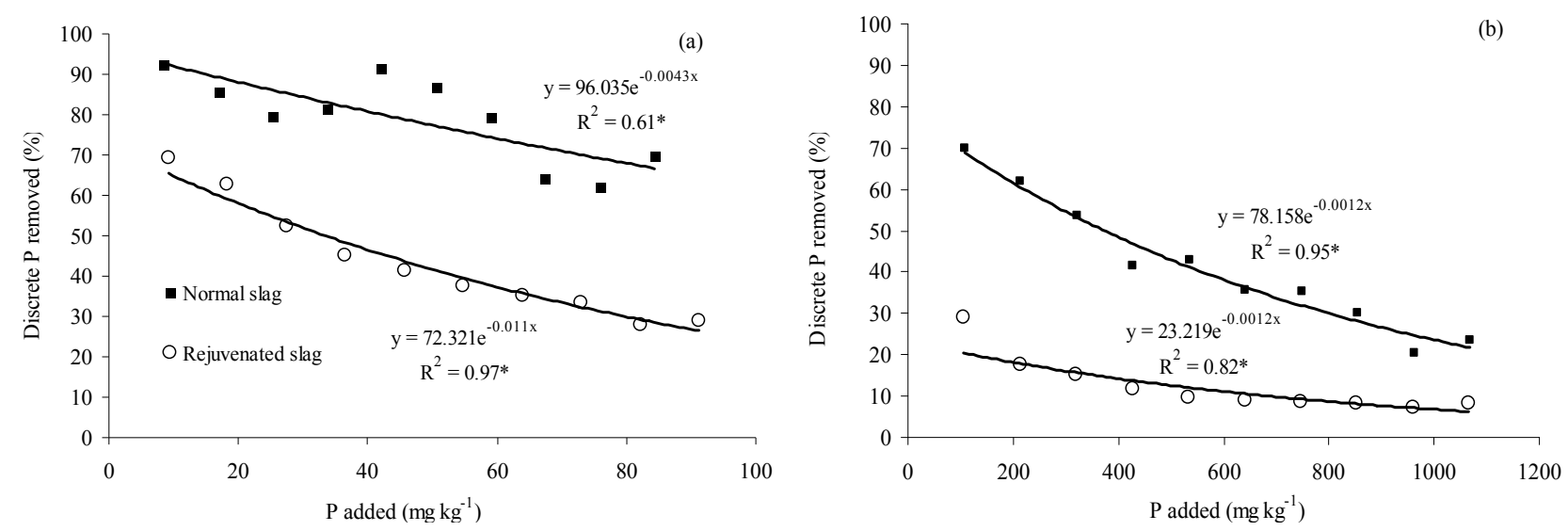

Figure 2. Example $P$ removal curves for normal and rejuvenated slag at (a) 6 minute retention time and $1 \mathrm{mg} \cdot P \cdot L^{-1} \mathrm{solution}$ and (b) 3 minute retention time and $10 \mathrm{mg} \cdot \mathrm{P} \cdot \mathrm{L}^{-1}$ solution.

\subsection{Large Scale Pond Flow-through Experiments}

A large scale flow-through unit was constructed to treat water in a small pond $\left(\sim 405 \mathrm{~m}^{2}\right)$ located at the at the Oklahoma State University turfgrass research farm. This pond receives subsurface drainage from research turfgrass plots and typically displays dissolved $\mathrm{P}$ concentrations $0.5 \mathrm{mg} \cdot \mathrm{L}^{-1}$; this was a "closed" system with no spillway. Please note that the purpose of this experiment was not to remediate the pond, instead the purpose was to test the materials in a flow-through setting at a large scale under more "natural" conditions. The flow-through unit was housed in a small plastic building (Suncast, Batavia, IL) and consisted of a $1 / 2$ horse power electric well pump (RC5, Waterace; Ashland, $\mathrm{OH}$ ) that delivered pond water into the top of a $960 \mathrm{~L}$ stock tank (Wylie polyethylene leg tank, Wylie, TX) that contained $454 \mathrm{~kg}$ of sieved slag. A drainage outlet at the bottom of the tank was connected to a $1.27 \mathrm{~cm}$ diameter hose which allowed treated water to return back to the pond. The water pump was wired to a float switch (FLT004, Chicago Sensor; Chicago, IL) that prevented overflow of the tank. The pump was also wired to a timer in order to control flow events; water was applied to the slag material for $20 \mathrm{~h} \cdot \mathrm{day}^{-1}$ allowing a $4 \mathrm{~h}$ rest period to prevent the pump from overheating. Treated and pre-treated water (i.e. outflow and inflow) was sampled at time 0,10 , and $19.5 \mathrm{~h}$ after initiation of a daily flow-through event. For the normal slag material, this occurred for 22 continuous days.

After the normal slag was "spent" (i.e. inflow = outflow P concentration), the material was washed in the tank with clean tap water (to remove sediment). After washing, a treatment process was initiated in situ for slag "rejuvenation". The idea was to precipitate amorphous Al hydroxide minerals on the surface of the alkaline slag material. Approximately $134 \mathrm{~L}$ of a $0.17 \mathrm{M}$ aluminum sulfate solution $\left(\mathrm{Al}_{2}\left[\mathrm{SO}_{4}\right]_{3} \cdot 12 \mathrm{H}_{2} \mathrm{O}\right)$ was poured into the tank (drain plugged), submersing all slag. Slag was "soaked" in the aluminum sulfate solution for $48 \mathrm{~h}$ before the drain plug was removed and all drainage water was collected and disposed of. This "rejuvenated slag" was allowed to air dry for one week. Approximately $1 \mathrm{~kg}$ of the rejuvenated slag was removed from the tank for future laboratory characterization and experimentation. Pond flow-through experimentation was then conducted in the same manner as the normal slag previously tested.

\subsection{Data Analysis and Model Development}

Discrete P sorption (\%) under flow-through conditions was averaged among replications and described as a function of $\mathrm{P}$ added to the materials $\left(\mathrm{mg} \cdot \mathrm{kg}^{-1}\right)$ using a exponential model (Figure 2). The relationship between discrete $\mathrm{P}$ sorption and $\mathrm{P}$ added for every $\mathrm{RT} * \mathrm{P}$ concentration combination was found to be statistically significant at $\mathrm{P}<0.05$ based on use of the SAS [23] "proc reg" command. Two multiple linear regression (MLR) models were then constructed to predict the slope and intercept of this "design curve" (Figure 2) as a function of $P$ concentration and RT. Because the slope and intercepts were not normally distributed, these parameters were log transformed before producing the MLR model. The MLR model was produced using the SAS "proc reg" command with RT and P concentration as the independent variables. All four MLR models (two for each material) were significant at $\mathrm{P}<0.01$. With knowledge of the equation for the discrete $\mathrm{P}$ sorption relationship, one can determine how much cumulative $\mathrm{P}$ is removed by integration of the exponential equation:

$$
\text { Cumulative P removed }(\%)=\frac{\int_{0}^{x}\left(b \mathrm{e}^{m x}\right) \mathrm{d} x}{x}
$$


Table 1. Characterization of the normal and rejuvenated slag.

\begin{tabular}{|c|c|c|c|c|c|c|c|c|c|c|c|c|c|}
\hline \multirow[b]{2}{*}{ Material } & \multirow[b]{2}{*}{$\mathrm{pH}$} & \multirow[b]{2}{*}{ Alkalinity } & \multicolumn{5}{|c|}{ Total $^{\dagger}$} & \multicolumn{5}{|c|}{ Water soluble } & \multirow[b]{2}{*}{$\begin{array}{c}\text { Crystalline } \\
\text { minerals }\end{array}$} \\
\hline & & & $\mathrm{Ca}$ & $\mathrm{Mg}$ & S & $\mathrm{Fe}$ & $\mathrm{Al}$ & $\mathrm{Ca}$ & $\mathrm{Mg}$ & $\mathrm{S}$ & $\mathrm{Fe}$ & $\mathrm{Al}$ & \\
\hline & & $\begin{array}{c}\mathrm{mg} \\
\mathrm{CaCO}_{3} \\
\mathrm{~kg}^{-1}\end{array}$ & \multicolumn{11}{|c|}{$\mathrm{mg} \mathrm{kg}^{-1}$} \\
\hline Normal & 10.9 & 766 & 256382 & 79043 & 6208 & 191776 & 32923 & 249 & 0.71 & 82 & 0 & 15 & $\begin{array}{c}\text { Portlandite, } \\
\text { Calcite, } \\
\text { Calcium } \\
\text { silicate }\end{array}$ \\
\hline Rejuvenated & 7.1 & 156 & 270023 & 72344 & 17771 & 152145 & 41100 & 5818 & 76 & 4654 & 0 & 2.5 & $\begin{array}{l}\text { Calcite, } \\
\text { gypsum }\end{array}$ \\
\hline
\end{tabular}

$\uparrow$ Determined by EPA3051 digestion method † Determined by X-ray diffraction

In this case, "cumulative $\mathrm{P}$ removed" is the total amount of $\mathrm{P}$ that has been sorbed by the material up to point $\mathrm{x}, \mathrm{P}$ added to the material in $\mathrm{mg} \cdot \mathrm{kg}^{-1}$. This is expressed as a percentage of $\mathrm{x}$. Variables $\mathrm{m}$ and $\mathrm{b}$ are the slope and intercept, respectively for the exponential relationship between $\mathrm{x}$ ( $\mathrm{P}$ added) and discrete $\mathrm{P}$ removal $(\%)$. The point at which the design curve approaches zero percent discrete $P$ removal represents the maximum amount of $P$ that can be added (in units of $\mathrm{mg} \cdot \mathrm{P} \cdot \mathrm{kg}^{-1}$ ) to the material at $\mathrm{P}$ saturation. In other words, this is the point at which the $\mathrm{P}$ concentration inflow $=\mathrm{P}$ concentration outflow. The amount of $\mathrm{P}$ added to reach this point of $\mathrm{P}$ saturation is described by the following function:

$$
\text { Maximum } \mathrm{P} \text { added }=\frac{\ln b}{-m}
$$

This value of maximum $\mathrm{P}$ added can then be inserted as variable " $\mathrm{x}$ " into Equation 2 along with the $\mathrm{m}$ and $\mathrm{b}$ values for that particular RT and $\mathrm{P}$ concentration of interest; the resulting cumulative $\mathrm{P}$ removed represents the maximum overall $\mathrm{P}$ removal under those conditions.

\section{Results and Discussion}

\subsection{Slag Characterization}

Saturated hydraulic conductivity of the sieved slag used in all experiments was high as expected at $0.68 \mathrm{~cm} \mathrm{~s}^{-1}$. In the context of a field $\mathrm{P}$ removal structure, a high conductivity translates to the ability to treat large amounts of runoff water in a smaller area. Total concentrations of $\mathrm{Ca}, \mathrm{Mg}, \mathrm{Fe}$, and $\mathrm{Al}$ (Table 1) were similar to those reported for EAF slag in previous studies $[15,24]$. The slag was dominated with $\mathrm{Ca}$ and $\mathrm{Fe}$ and the $\mathrm{pH}$ for the normal slag was relatively high (10.9; Table 1). Normal slag possessed some alkalinity but this was small compared to the finer sized fractions typically reported. For example, when expressed as calcium carbonate equivelant (CCE), normal slag contained only
$0.07 \%$ compared to 18 to $80 \%$ reported for the fine fractions [25]. The elevated $\mathrm{pH}$ and $\mathrm{Ca}$ concentrations are typical considering the presence of portlandite $\left(\mathrm{Ca}[\mathrm{OH}]_{2}\right)$, calcite $\left(\mathrm{CaCO}_{3}\right)$, and calcium silicate $\left(\mathrm{Ca}_{2} \mathrm{SiO}_{4}\right)$ identified by X-ray diffraction (Table 1).

After the normal slag was saturated with $\mathrm{P}$ from use in the pond filter and subsequent treatment with aluminum sulfate solution, some chemical properties were altered. The rejuvenated slag appeared visibly different from normal slag in that the former contained a white precipitant powder around the individual slag pieces. The most obvious chemical changes included a decrease in $\mathrm{pH}$ and alkalinity and increase in total $\mathrm{S}, \mathrm{Al}$, water soluble $\mathrm{Ca}$ and $\mathrm{S}$ (Table 1). Acidification treatment with aluminum sulfate clearly decreased $\mathrm{pH}$ and added $\mathrm{Al}$ and S. Dissolution of the Ca hydroxide (i.e. portlandite) and calcite minerals via acidification not only increased the water solubility of $\mathrm{Ca}$ but also resulted in the formation of gypsum $\left(\mathrm{CaSO}_{4}\right)$ with the added $\mathrm{S}$ from aluminum sulfate. Water soluble $\mathrm{Al}$ decreased with treatment due to the decrease in $\mathrm{pH} ; \mathrm{Al}$ becomes soluble at alkaline and acid $\mathrm{pH}$ but is precipitated as Al hydroxide minerals at near neutral $\mathrm{pH}$. The increase in total $\mathrm{Al}$ from aluminum sulfate treatment is likely in the form of an amorphous Al hydroxide since no Al minerals were detected by X-ray diffraction.

In order for the $\mathrm{Ca}$ contained in slag materials to effectively precipitate $\mathrm{P}$ from solution, the $\mathrm{Ca}$ must be soluble and the solution $\mathrm{pH}$ buffered above $6.5[10,12]$. Although the normal slag has less soluble Ca compared to the slag, the alkalinity and $\mathrm{pH}$ of normal slag is higher than rejuvenated slag, potentially making the soluble $\mathrm{Ca}$ more effective at precipitating $\mathrm{P}$ from solution. Kostura et al. [12] demonstrated that the acid neutralizing capacity of crystalline and amorphous slags were well related to the $\mathrm{P}$ saturation capacity. The soluble $\mathrm{Ca}$ found in rejuvenated slag is likely in the form of gypsum, which has been shown to be a somewhat effective $\mathrm{P}$ sorbent [26]. In addition, the 
amorphous $\mathrm{Al}$ hydroxides formed in the rejuvenated slag would be an effective $\mathrm{P}$ sorbent via ligand exchange of $\mathrm{P}$ onto terminal hydroxide groups; this mechanism would also occur on any $\mathrm{Fe}$ oxide/hydroxide minerals present in either material.

The traditional batch isotherm data fit well to the Langmuir model as indicated by an E value of 0.83 and 0.93 for normal and slag, respectively. The normal slag displayed a higher $\mathrm{K}$ value than rejuvenated slag (2.43 vs. 0.209; standard error $=0.18$ and 0.075 for normal and slag, respectively). A larger $\mathrm{K}$ value is often considered to indicate greater affinity" for $\mathrm{P}$ compared to lesser values. On the other hand, $\mathrm{S}_{\max }$ was less for normal slag compared to rejuvenated slag (686 vs. $1229 \mathrm{mg} \cdot \mathrm{kg}^{-1}$; standard error $=88$ and 139 for normal and slag, respectively). The higher $\mathrm{K}$ value for normal slag may be due to the greater "potency" of the dissolved $\mathrm{Ca}$ in normal slag to precipitate $\mathrm{P}$ since this material possessed a higher $\mathrm{pH}$ and alkalinity compared to the rejuvenated slag. However, at higher concentrations of added $\mathrm{P}$ combined with greater soluble $\mathrm{Ca}$ concentrations of rejuvenated slag, the rejuvenated slag may sorb more $\mathrm{P}$ than normal slag as suggested by the higher $S_{\max }$ of rejuvenated slag.

\subsection{Flow-Through Phosphorus Sorption}

Phosphorus sorption under flow-through conditions was described as a function of $\mathrm{P}$ added to the materials using an exponential function (Figure 2). The exponential function was statistically significant for every $P$ concentration and RT. Utilizing all P concentrations and RTs tested, two MLR models were found to be statistically significant $(\mathrm{P}<0.01)$ for predicting the slope (m) and intercept (b) for the relationship between $\mathrm{P}$ added $\left(\mathrm{mg} \cdot \mathrm{kg}^{-1}\right)$ and discrete P removal (\%) as a function of $\mathrm{P}$ concentration and RT for normal slag:

$$
\log (-m)=(0.08506 \cdot \mathrm{RT})-(0.07416 \cdot \mathrm{P} \text { concentration })
$$$$
-2.53493
$$

$\log b=(0.06541 \cdot \mathrm{RT})-(0.00864 \cdot \mathrm{P}$ concentration $)$

$+1.60631$

For rejuvenated slag:

$\log (-m)=(0.08551 \cdot \mathrm{RT})-(0.07149 \cdot \mathrm{P}$ concentration $)$ $-2.4399$

$\log b=(0.05956 \cdot \mathrm{RT})-(0.0352 \cdot \mathrm{P}$ concentration $)$ $+1.61715$
The $\mathrm{r}$ squared values for slope and intercept Equations (4 to 7) for normal slag were 0.68 and 0.48 , respectively, and 0.72 and 0.83 for rejuvenated slag. In general, the flow through curves for the normal and rejuvenated slag were similar in slope (m), yet rejuvenated slag always had a lower Y intercept (b) than normal slag, especially at high $\mathrm{P}$ concentrations. One example of this is shown in Figure 2. This difference in $b$ is also observed in the MLR by comparing Equation 5 to 7 ; due to the $\mathrm{P}$ concentration coefficient being four times as high in rejuvenated than normal slag, the differences in intercepts become greater with increasing $\mathrm{P}$ concentrations. The $\mathrm{b}$ value for normal slag also increases more with increasing RT compared to rejuvenated slag due to the larger RT coefficient for normal slag shown in Equations 5 and 7 (0.065 41 vs. 0.05956 for normal and rejuvenated slag, respectively).

The lower $\mathrm{b}$ values for the rejuvenated compared to normal slag is likely a result of the lower "potency" of the dissolved $\mathrm{Ca}$ in rejuvenated slag due to lower $\mathrm{pH}$ and alkalinity (Table 1). This difference is also reflected in the greater Langmuir $\mathrm{K}$ value previously discussed for the normal slag. Previous studies have also shown that $\mathrm{P}$ sorption with slag is enhanced with increasing $\mathrm{pH}$ and alkalinity [12-13].

\subsection{Flow-through vs. Batch Isotherm Phosphorus Sorption}

Due to differences in the nature of the batch isotherm compared to the flow-through experimentation, the amount of $\mathrm{P}$ sorbed by these methods should also differ. Figure 3 shows the differences between each approach by applying the $\mathrm{P}$ concentrations tested in the flow through experimentation $\left(0.5,1,5,10\right.$, and $\left.15 \mathrm{mg} \cdot \mathrm{L}^{-1}\right)$ to the Langmuir Equation (1) and MLR equations (at $\mathrm{RT}=0.5 \mathrm{~min}$ ) describing flow-through $\mathrm{P}$ sorption (Equations 4 to 7). Note that Equations 2 and 3 are also necessary for estimating the cumulative $\mathrm{P}$ removed from the predicted discrete curves. The "equilibrium point" in the flow-through condition is defined as the point in which the concentration of $\mathrm{P}$ added equals the concentration of $\mathrm{P}$ in the leachate, or "treated water" (i.e. when discrete $\mathrm{P}$ removal $=0$ ). For the normal slag, Figure 3 indicates that a batch isotherm greatly underestimates $\mathrm{P}$ sorption at a high $\mathrm{P}$ concentration (15 $\left.\mathrm{mg} \cdot \mathrm{P} \cdot \mathrm{L}^{-1}\right)$. On the other hand, the batch system mostly sorbed more $\mathrm{P}$ than flow-through for rejuvenated slag as concentrations increased.

The most important differences between the batch isotherm and the flow-through system are the RT and constant addition of reactants coupled with removal of reaction products. Therefore, there is a "balance" betw- 


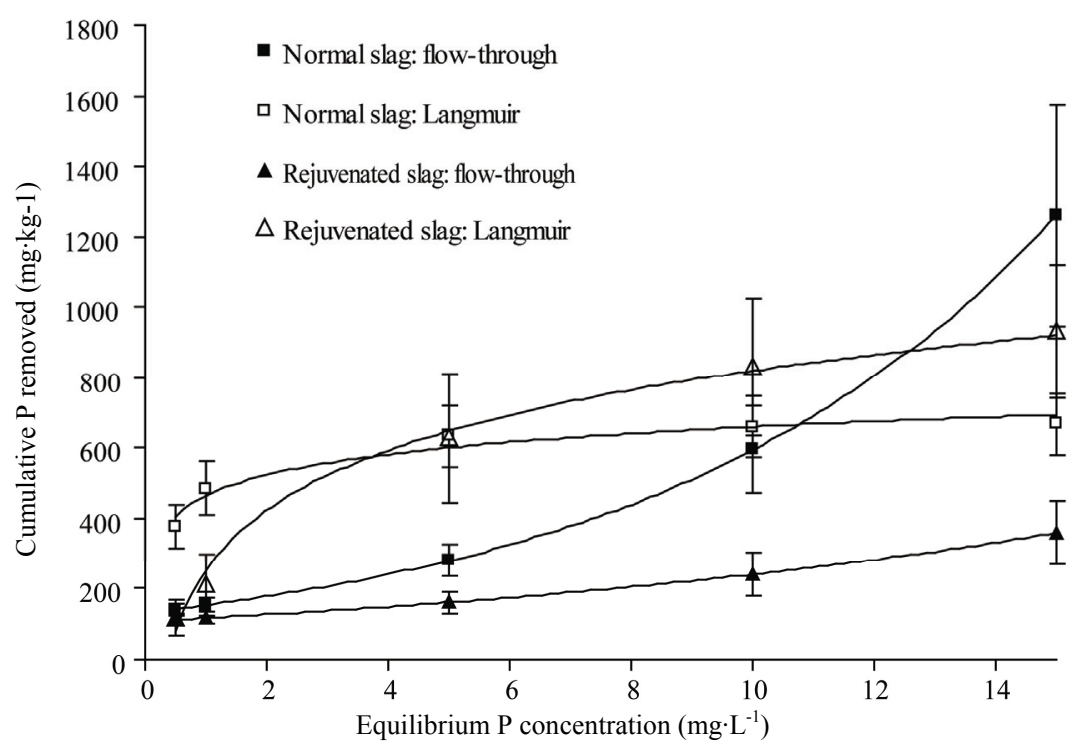

Figure 3. Phosphorus (P) sorption by normal and rejuvenated slag as predicted by the flow-through model (Equations 2 , and 4 to 7) and Langmuir equation (Equation 1). Flow-through model predictions based on a retention time of $30 \mathrm{~s}$ and Langmuir predictions are based on the $S_{\max }$ and $K$ values determined in the batch equilibration experiment. Equilibrium $P$ concentrations plotted are those tested in flow-through experimentation: $0.5,1,5,10$, and $15 \mathrm{mg} \cdot \mathrm{L}^{-1}$. Error bars indicate standard error.

Table 2. Long-term phosphorus (P) removal performance of the materials tested on a pond. Actual $P$ removal compared to predicted removal using flow-through equations (Equations 2 and 4 to7) and Langmuir isotherm (Equation 1).

\begin{tabular}{lccc}
\hline \multicolumn{1}{c}{ Parameter } & & Normal slag & Rejuvenated slag \\
\hline Duration tested & $(\mathrm{days})$ & 20 & 20 \\
P Input Range & $\left(\mathrm{mg} \cdot \mathrm{L}^{-1}\right)$ & 0.11 to 0.60 & 0.16 to 0.52 \\
Flow weighted concentration & $\left(\mathrm{mg} \cdot \mathrm{L}^{-1}\right)$ & 0.38 & 0.34 \\
Total P added & $\left(\mathrm{mg} \cdot \mathrm{kg}^{-1}\right)$ & 172 & 149 \\
Mass material & $(\mathrm{kg})$ & 454 & 454 \\
Retention time & $(\mathrm{min})$ & 10 & 10 \\
Measured P removed & $\left(\mathrm{mg} \cdot \mathrm{kg}^{-1}\right)$ & 59 & 54 \\
Flow-through predicted P removed & $\left(\mathrm{mg} \cdot \mathrm{kg}^{-1}\right)$ & 88 & 62 \\
Langmuir isotherm predicted P removed & $\left(\mathrm{mg} \cdot \mathrm{kg}^{-1}\right)$ & 329 & 82 \\
\hline
\end{tabular}

een these factors that promote and inhibit Ca phosphate precipitation. For example, the longer RT of the batch system (or a long compared to a short RT within a flowthrough system) will provide more time for precipitation, promoting $\mathrm{Ca}$ phosphate precipitation. However, the nature of the batch system relative to flow-through also means that less reactants are being added to the system (i.e. not maintaining elevated $\mathrm{H}_{2} \mathrm{PO}_{4}{ }^{-}$concentration) and also reaction products are not removed as efficiently, which would reduce precipitation or P removal. A long RT may also allow the counter ion of the source $\mathrm{Ca}$ mineral (i.e. $\mathrm{SO}_{4}^{2-}$ or $\mathrm{CO}_{3}^{2-}$ ) to accumulate, which would prevent further dissolution of the minerals translating to a lower "supply" of $\mathrm{Ca}^{2+}$ thereby reducing precipitation (i.e. common ion effect).

For the normal slag in Figure 3, it appears that constant removal of reaction products was dominant over a greater amount of time for precipitation in the batch system at all concentrations above $11 \mathrm{mg} \cdot \mathrm{P} \cdot \mathrm{L}^{-1}$. On the other hand, the batch system displayed higher $\mathrm{P}$ retention than flow-through at lower equilibrium $\mathrm{P}$ concentrations (i.e. less than $11 \mathrm{mg} \cdot \mathrm{L}^{-1}$ ). This may be due to the greater amount of time for precipitation/reaction for the batch system and/or because of differences in the 

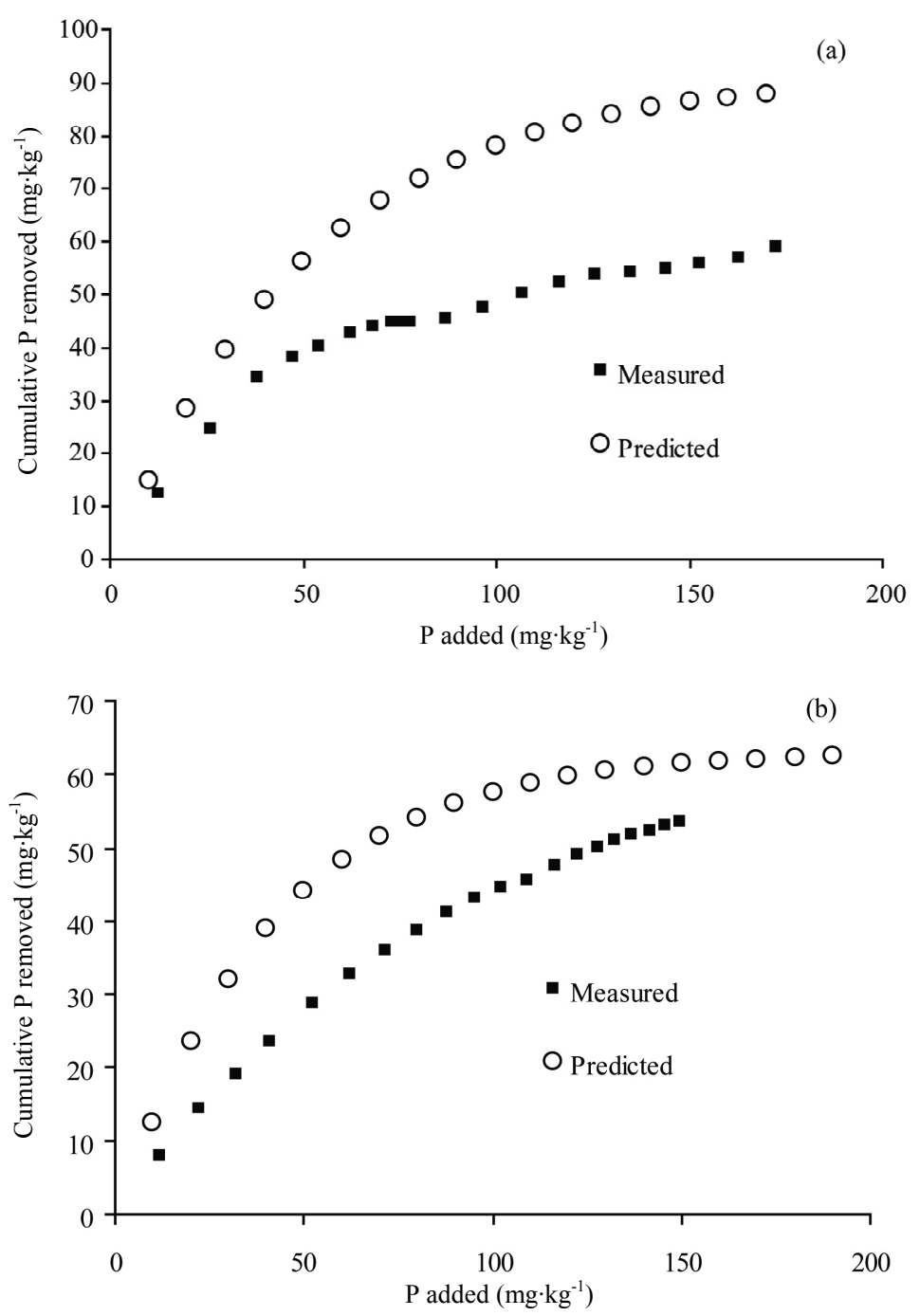

Figure 4. Cumulative Phosphorus (P) sorbed with $P$ added among normal (a) and treated (b) slag tested in the pond filtration unit. Open circles indicate model estimates from Equations 2 and 4 to 7 . Flow rate was $8.5 \mathrm{~L} \cdot \mathrm{min}^{-1}$ and pond water was pumped into materials for $20 \mathrm{~h}$ per day $(10,200 \mathrm{~L}$ per day). Details on experiment parameters and results shown in Table 2.

initial concentration of $\mathrm{P}$ added to the system. For example, in order for the batch system to achieve the equilibrium concentration of $5 \mathrm{mg} \cdot \mathrm{P} \cdot \mathrm{L}^{-1}$, a $\mathrm{P}$ solution concentration of approximately $38 \mathrm{mg} \cdot \mathrm{L}^{-1}$ was required. This greater initial $\mathrm{P}$ concentration compared to the flowthrough methodology $\left(5 \mathrm{mg} \cdot \mathrm{P} \cdot \mathrm{L}^{-1}\right)$ provided the greater chemical potential for precipitation and adsorption reactions to occur.

For the rejuvenated slag the greater RT of the batch system providing more time for precipitation appeared to dominate over the ability to remove reaction products at high equilibrium $\mathrm{P}$ concentrations. This contrary result relative to normal slag is likely due to the lower $\mathrm{pH}$ and alkalinity of rejuvenated slag compared to normal slag. In order for the soluble $\mathrm{Ca}$ to be most effective at $\mathrm{P}$ sorption the $\mathrm{pH}$ must be maintained above 6.5.

\subsection{Results of Pond Flow-through Experiment}

Results of the large scale pond flow-through experiment utilizing normal and rejuvenated slag are shown in Fig. 4. Similar to results from laboratory flow-through experiments and the subsequent MLR model (Equations 4 to 7), the decrease in discrete $\mathrm{P}$ removal with $\mathrm{P}$ addition between materials is similar but the initial $\mathrm{P}$ removal (i.e. $\mathrm{Y}$ intercept) was greater for normal than rejuvenated slag (data not shown). Pond $\mathrm{P}$ conditions were similar for each experiment (Table 2). The $\mathrm{pH}$ of pond water during this experiment was 7.2 to 8.0 , which was in the typical range for this particular pond prior to initiation of pumping. Actual P removal was 59 and 54 $\mathrm{mg} \cdot \mathrm{P} \cdot \mathrm{kg}^{-1}$ overall (i.e. cumulative) for normal and rejuvenated slag, respectively. Although the RT and $\mathrm{P}$ 
concentrations were slightly out of the range of flowthrough model development conditions (i.e. RT $>8 \mathrm{~min}$ and $\mathrm{P}<0.5 \mathrm{mg} \cdot \mathrm{L}^{-1}$; Table 2 ), the predictions were reasonable (Figure 4 and Table 2). Based on the calculated total pore volume and measured flow rate through the slag $\left(17.2 \mathrm{~L} \cdot \mathrm{min}^{-1}\right)$, the retention time for both materials was $10 \mathrm{~min}$.

Flow-through Equations (4 to 7) slightly over predicted cumulative $\mathrm{P}$ removal for normal slag and rejuvenated slag when the respective RT and flow-weighted P concentrations were applied (Table 2). On the other hand, the Langmuir model (Equation 1) highly over predicted cumulative P removal for the normal slag and slightly over predicted for the rejuvenated slag (Table 2) based on the $\mathrm{K}$ and $\mathrm{S}_{\max }$ values determined from the batch isotherm. These results clearly suggest the superiority of a flow-through model over a Langmuir batch isotherm for conditions in which a $P$ rich solution is passing through sorptive materials.

\section{Conclusions}

The materials examined in this study would be effective at scrubbing dissolved $\mathrm{P}$ from runoff when placed in $\mathrm{P}$ removal structures designed to intercept runoff [7-8]. Since the concept behind such structures is to remove and replace "spent" material after it has been saturated with P [7], the ability to successfully "rejuvenate" the slag material in situ via treatment process with aluminum sulfate as demonstrated in the current study will save considerable cost, time, and effort.

The flow-through model approach used in this study could be used in predicting the lifetime of materials in $P$ removal structures or determining how much material is required for achieving a target $\mathrm{P}$ removal goal for a specific site. For example, we are currently constructing a $\mathrm{P}$ removal structure on a golf course ditch where dissolved P concentrations are typically $0.6 \mathrm{mg} \cdot \mathrm{L}^{-1}$. Based on the slag mass $(2700 \mathrm{~kg})$ and target RT, the model predicts $31 \%$ cumulative $\mathrm{P}$ removal at saturation or 97 $\mathrm{mg} \cdot \mathrm{P} \cdot \mathrm{kg}^{-1}$. Based on expected runoff flow volumes for the site, the $2700 \mathrm{~kg}$ of slag would last about 15 to 24 months. Slag will then be treated in-situ for rejuvenation.

\section{References}

[1] J. N. Quinton, J. A. Catt and T. M. Hess, "The Selective Removal of Phosphorus from Soil: Is Event Size Important?" Journal of Environment Quality, Vol. 30, No. 2, 2001, pp. 538-546. doi:10.2134/jeq2001.302538x

[2] D. R. Edwards and T. C. Daniel, "Effects of Poultry litter Application Rate and Rainfall Intensity on Quality of Runoff from Fescuegrass Plots," Journal Environment Quality, Vol. 22, No. 2, 1993, pp. 361-365. doi:10.2134/jeq1993.00472425002200020017x
[3] C. J. Penn, G. L. Mullins, L. W. Zelazny, J. G. Warren, and J. M. McGrath, "Surface Runoff Losses of Phosphorus from Virginia Soils Amended with Turkey Manure Using Phytase and HAP Corn Diets," Journal of Environment Quality, Vol. 33, No. 4, 2004, pp.14311439. doi:10.2134/jeq2004.1431

[4] J. W. Leader, E. J. Dunne, and K. R. Reddy, "Phosphorus Sorbing Materials: Sorption Dynamics and Physiochemical Characteristics," Journal of Environment Quality, Vol. 37, No. 1, 2008, pp. 174-81.

doi: $10.2134 /$ jeq2007.0148

[5] L. E. Gallimore, N. T. Basta, D. E. Storm, M. E. Payton, R. H. Huhnke and M. D. Smolen, "Water Treatment Residual to Reduce Nutrients in Surface Runoff from Agricultural Land," Journal Environmrnt Quality, Vol. 28, No. 5, 1999, pp. 1474-1478.

\section{doi:10.2134/jeq1999.00472425002800050012x}

[6] C. J. Penn, and R. B. Bryant, "Application of PhoSphorus Sorbing Materials to Streamside Cattle Loafing Areas," Journal of Soil and Water Conservation, Vol. 61, No. 5, 2006, pp. 303-310.

[7] C. J. Penn, R. B. Bryant, P. A. Kleinman and A. Allen, "Sequestering Dissolved Phosphorus from Ditch Drainage Water," Journal of Soil and Water Conservation, Vol. 62, No. 4, 2007, pp. 269-272.

[8] C. J. Penn, J. M. McGrath and R. B. Bryant, "Ditch Drainage Management for Water Quality Improvement," In: M. T. Moore and R. Kroger Eds., Agricultural Drainage Ditches: Mitigation Wetlands for the 21st Century, Research Signpost, Kerala, India, 2010, pp. 151-173.

[9] A. N. Shilton, I. Elmetri, A. Drizo, S. Pratt, R. G. Haverkamp and S. C. Bilby, "Phosphorus Removal by an "Active" Slag Filter-A Decade of Full Scale Experience," Water Research, Vol. 40, No. 1, 2006, pp. 113-118. doi:10.1016/j.watres.2005.11.002

[10] L. Johansson, "Industrial By-Products and Natural Substrate as Phosphorus Sorbents," Environmental Technology, Vol. 20, No. 3, 1999, pp. 309-316. doi: $10.1080 / 09593332008616822$

[11] R. W. McDowell, A. N. Sharpley and W. Bourke, "Treatment of Drainage Water with Industrial ByProducts to Prevent Phosphorus Loss from Tile-Drained Land," Journal of Environment Quality, Vol. 37, No. 4, 2008, pp. 1575-1582. doi:10.2134/jeq2007.0454

[12] B. Kostura, H. Kulveitova and J. Lesko, "Blast Furnace Slags as Sorbents of Phosphate from Water Solutions," Water Research, Vol. 39, No. 9, 2005, pp. 1795-1802.

[13] L. I. Bowden, A. P. Jarvis, P. L. Younger and K. L. Johnson, "Phosphorus Removal from Waste Waters Using Basic Oxygen Steel Slag," Environmental Science \& Technology, Vol. 43, No. 7, 2009, pp. 2476-2481. doi:10.1021/es801626d

[14] A. Drizo, C. Forget, R. P. Chapuis and Y. Comeau, "Phosphorus Removal by Electric Arc Furnace Steel Slag and Serpentine," Water Research, Vol. 40, No. 8, 2006, pp. 1547-1554. doi:10.1016/j.watres.2006.02.001 
[15] A. Drizo, Y. Comeau, C. Forget and R. P. Chapuis, "Phosphorus Saturation Potential: A Parameter for Estimating the Longevity of Constructed Wetland Systems," Environmental Science \& Technology, Vol. 36, No. 21, 2002, pp. 4642-4648. doi: $10.1021 / \mathrm{es} 011502 \mathrm{v}$

[16] A. Drizo, J. Cummings, D. Weber, E. Twohig, G. Druschel and B. Bourke, "New Evidence for Rejuvenation of Phosphorus Retention Capacity in EAF Steel Slag," Environmental Science \& Technology, Vol. 42, No. 16, 2008, pp. 6191-6197. doi:10.1021/es800232r

[17] U. S. Environmental Protection Agency, "Method 3051a: Micro-Wave Assisted Acid Dissolution of Sediments, Sludges, Soils and Oils," 2nd Edition," U.S. Government Printing Office, Washington, DC, 1997.

[18] A. Klute and C. Dirksen, "Hydraulic Conductivity and Diffusivity: Laboratory Methods," In: A. Klute, Ed., Methods of Soil Analysis, Part 1 SSSA Book Series 5, SSSA, Madison, WI, 1986, pp. 687-732.

[19] J. Murphy and J. R. Riley, "A Modified Single Solution Method for the Determination of Phosphate in Natural Waters," Analytica Chimica Acta, Vol. 27, No. 1, 1962, pp. 31-36. doi:10.1016/S0003-2670(00)88444-5

[20] C. H. Bolster and G. M Hornberger, "On the Use of Linearized Langmuir Equations," Soil Science Society of Amercia Journal, Vol. 71, No. 6, 2007, pp. 1796-1806. doi:10.2136/sssaj2006.0304
[21] T. M. DeSutter, G. M. Pierzynski and L. Baker, "Flowthrough and Batch Methods for Determining $\mathrm{Ca}-\mathrm{Mg}$ and Mg-Ca Selectivity," Soil Science Society of Amercia Journal, Vol. 70, No. 2, 2006, pp. 550-554. doi:10.2136/sssaj2005.0065N

[22] P. A. Vadas, R. D. Harmel and P. J. A. Kleinman, "Transformations of Soil and Manure Phosphorus after Surface Application of Manure to Field Plots," Nutrient Cycling Agroecosystms, Vol. 77, No. 1, 2007, pp. 83-99. doi:10.1007/s10705-006-9047-5

[23] SAS Institute, "SAS User's Guide: Statistics," SAS Inst., Cary, NC, 2003.D. M. Proctor, K. A. Fehling, E. C. Shay, J. L. Witt-enborn, J. J. Green, C. Avent, R. D. Bigham, M. Connolly, B. Lee, T. O. Shepker and M. A. Zak, "Phy-sical and Chemical Characteristics of Blast Furnace, Basic Oxygen Furnace, and Electric Arc Furnace Steel Industry Slags," Environmental Science \& Technology, Vol. 34, No. 8, 2000, pp. 1576-1582. doi:10.1021/es9906002

[24] National Slag Association, "A Guide For The Use of Steel Slag in Agriculture and for Reclamation of Acid Lands," 2011. Internet available: http://www.mational slag.org/tech/ag_guide909.pdf

[25] C. J. Penn, R. B. Bryant, M. A. Callahan and J. M. McGrath, "Use of Industrial by-Products to Sorb and Retain Phosphorus," Communications in Soil Science and Plant Analysis, 2011, In print. 